\title{
Neotypification of Drawida hattamimizu Hatai, 1930 (Annelida, Oligochaeta, Megadrili, Moniligastridae) as a model linking mtDNA (COI) sequences to an earthworm type, with a response to the 'Can of Worms' theory of cryptic species
}

\author{
R.J. Blakemore', E.K. Kupriyanova², M.J. Grygier ${ }^{3}$
}

I C/- 2 Faculty of Education and Human Sciences, Yokohama National University (YNU), Tokiwadai, Hodogaya, Yokohama 240-8501 3 Lake Biwa Museum (LBM), Oroshimo 1091, Kusatsu-shi, Shiga-ken 525-0001, Japan

Corresponding author: R.J. Blakemore (rob.blakemore@gmail.com)

Academic editor: Lyubomir Penev | Received 19 December 2009 | Accepted 3 March 2010 | Published 26 March 2010

Citation: Blakemore RJ, Kupriyanova EK, Grygier MJ (2010) Neotypification of Drawida hattamimizu Hatai, 1930 (Annelida, Oligochaeta, Megadrili, Moniligastridae) as a model linking mtDNA (COI) sequences to an earthworm type, with a response to the 'Can of Worms' theory of cryptic species. ZooKeys 41: 1-29. doi: 10.3897/zookeys.41.374

\begin{abstract}
A neotype is designated for the large and ecologically interesting species of Japanese earthworm, Drawida hattamimizu Hatai, 1930. Its morphological redescription is unambiguously combined with the neotype's sequence of the Cytochrome Oxidase I (COI) locus of the mitochondrial DNA, the first time an earthworm species' type has been thus profiled. Probably it is an introduced exotic rather than a translocated native, with a patchy distribution that appears only partly defined in Japan where it is both a restricted and an endangered listed species. Brief comparison of sympatric Drawida japonica (Michaelsen, 1892) to the type-species Drawida barwelli (Beddard, 1886) - and this latter from Shiga appears as a new record for Japan - allows the diagnosis of Drawida Michaelsen, 1900 to be amended slightly. The contentious issue of molecular 'cryptic species' is queried in relation to the lack of molecular data from type-specimens, the unique name-bearing references employed in zoological nomenclature. Without such reference, neither eco-taxonomic nor genomic studies of earthworm taxa can progress. In this regard, questions are raised concerning the molecular identities and provisional divergences of cosmopolitan generotypes Allolobophora chlorotica chlorotica (Savigny, 1826), the Aporrectodea caliginosa (Savigny, 1826) species-complex sensu Blakemore (2002), and of ecotoxicological standard test-species icon Eisenia fetida fetida (Savigny, 1826). Resurrection of their respective synonyms is mooted. Resolution of relationships within and between earthworm genera and families without DNA testing of the representative type-species and type-genera is flagged as another crucial concern.
\end{abstract}

Copyright R.J. Blakemore et al.. This is an open access article distributed under the terms of the Creative Commons Attribution License, which permits unrestricted use, distribution, and reproduction in any medium, provided the original author and source are credited. 


\section{Keywords}

Lumbricidae, neotype, biodiversity, parthenogenesis, provisional species, COI barcode, OTUs, genomic phylogeny, genetic synonymy, ICZN

\section{Introduction}

Drawida hattamimizu Hatai, 1930 is the largest earthworm known in Japan, reaching ca. 1,000 $\mathrm{mm}$ in length. It is recognized as both a geographically restricted and as an endangered species in the Red Data Book of Japan (Anon. 2007) and that of Ishikawa Prefecture (Anon. 2009), being reported only from Kanazawa (type locality) to Lake Biwa in central Honshu. Its transportation away from inhabited paddies was voluntarily regulated by rice farmers since its burrows in paddy embankments supposedly drained the paddies to the detriment of the crop (Hatai 1930). Possibly it is an introduced species as yet unreported from its overseas homeland, rather than a translocated native or neoendemic, with a patchy distribution that is only partly documented in Japan. In the first comprehensive review of Japanese earthworms, Easton (1981:37) raised doubts and questioned its identity when he said for Japanese Drawida: "None of the eight species considered here is particularly well known and the specific status of each requires closer investigation"; in his Table 1 of Marker Characters he included two "?"s for D. hattamimizu and some other features were poorly defined [see http://www.archive.org/stream/bulletinofbritis 40zoollond\#page/38/mode/2up]; he also (erroneously) included Hokkaido in its distribution. Its type material cannot be traced, thus a topotypic specimen kept in $85 \%$ Ethanol $(\mathrm{EtOH})$ at room temperature for around 7 years is designated as the neotype, and tissue from it has been used in the present study for DNA analysis (COI gene barcoding). This procedure provides a model for DNA barcoding of other earthworm types, without which eco-taxonomic studies in Japan, as elsewhere, especially where there is a prevalence of similar or parthenogenetic morphs, cannot progress far owing to the likely proliferation of mutually uncoordinated parataxonomies.

Problems in conventional systematics and taxonomy of megadrile earthworms are: lack of specialists, poor species descriptions, missing historical types, closely similar morphs and rampant parthenogenesis. Earthworm DNA barcoding offers a solution (Folmer et al. 1994; Siddal et al. 2001; 2009; Huang et al. 2007; Chang et al. 2009; Rougerie et al. 2009) but no previous work has yet sampled from either a species' type specimen or from a type-species of a genus. Although (ICZN, 1999: Art. 72.3) mandates fixation of a type for a new name, an ongoing obstacle is lack of types for older described species thereby precluding effective and efficient barcoding. This study attempts to remedy this for at least one enigmatic Drawida species in Japan belonging to the large Indo-oriental Family Moniligastridae Claus, 1880. 
Especially Japanese earthworm taxonomy is in a desperately chaotic state with between 70 or 160+ nominal taxa including many homonyms and synonyms, plus parthenogenetic polymorphs of both natives and exotics in which just those anatomical characters needed to differentiate between species are degraded (Easton 1981; Blakemore 2003, 2007a, 2008a, in press). DNA sequence analysis is the only feasible means of resolving parthenogenetic clones or immature forms of earthworms, but only when initially referenced to a species' type. Few of the Japanese taxa are adequately described, many classical taxa lack types, and there is an urgent and exceptional need to perform molecular analyses to meet the aims of ICZN nomenclature for "stability and universality" thereby enabling ecological studies. Without this, the ambiguity and uncertainty of earthworm biodiversity will be compounded in Japan, and taint adjacent countries such as Korea, China or Russia. Despite the close proximity of some of these neighbours, and obvious similarity between their shared faunas, little attempt has been made to apply the Principle of Priority (ICZN 1999: Art. 23) and many new nationalistic taxonomic names have been precipitously published, further deferring resolution by adding complexity to existing systematic difficulty (see Blakemore 2003, 2008a, 2009, in press).

One of the earliest molecular studies of Annelida, which included a few earthworms, was by Siddall et al. (2001), and Siddall et al. (2009) summarize some intervening issues that specifically relate to success of DNA barcoding. Molecular studies of earthworms in general have been relatively rare and mostly restricted to a few groups such as holarctic Lumbricidae, yet even these have not considered type specimens. Gregory and Hebert (2002) recognized the ecological and economic importance of earthworms but stated: "Unfortunately, this importance appears not to have translated into interest among genome biologists. In fact, the genomic properties of oligochaetes have been almost totally ignored." Addressing this lapse, Blakemore (2009) and Stürzenbaum et al. (2009) provide some historical and predictive information on earthworm studies, particularly those made famous by Darwin (1881), commenting generally on genomic research.

In a recent study, the "first thought" of King et al. (2008) was to claim to "open a can of worms" by reporting "unprecedented sympatric cryptic diversity within British lumbricid earthworms" in the form of molecular cryptic species that "has profound consequences for all areas of earthworm research." But these authors did not anchor their work with comparison to the types of any of the species they claimed to study. Their conclusions, as with all previous molecular or DNA analyses of earthworms, were thus ungrounded. These and other issues of genetic analysis and GenBank accession are discussed further in the context of the current study based on the type of a known species.

Protocols for the Consortium for the Barcode of Life (CBOL 2010) recommend fresh or frozen sample material from voucher specimens. An ancillary aim of the current study was to demonstrate that molecular analysis of preserved earthworms via DNA extraction and amplification using current technology is possible from 'older' type material. 


\section{Methods}

From among several specimens of Drawida hattamimizu collected from the type locality (Hatta-cho, Kanazawa, Ishikawa Prefecture) a suitably mature and complete exemplar was selected, anaesthetized in dilute ethanol until immobile, then fixed and preserved in $85 \%$ ethanol $(\mathrm{EtOH})$ in a sufficiently large and robust jar. This specimen was not frozen, but was maintained at ambient room temperature for several years $(-7$ yr) before DNA extraction, amplification and sequencing (COI barcoding) was finally successfully achieved from small (ca. $<5 \mathrm{~mm}^{2}$ ) integument tissue samples taken from non-essential, iterative, posterior segments that yet lie slightly in front of the terminus wherein parasitic debris and coelomocytes tend to accumulate in earthworms. Other Drawida specimens were sampled for comparison as detailed below. All specimens are deposited in the Lake Biwa Museum, Shiga Prefecture, Japan (LBM).

\section{DNA extration, amplification and sequencing}

Before genomic DNA extractions, ethanol (EtOH) was removed from samples by washing tissues three times in $0.5 \mathrm{ml}$ of seawater. Qiagen DNeasy Kit for total DNA extraction (proteinase $\mathrm{K}$ digestion in lysis buffer and spin filter method) was used according to manufacturer's instructions. Stock DNA was diluted 1:10 with deionized water to produce template strength DNA for Polymerase Chain Reactions (PCR).

A fragment of the COI gene (approximately $600 \mathrm{bp}$ ) was amplified using standard Folmer primers (Folmer et al. 1994) and, for the neotype only on its second and final attempt, with a modified Folmer reverse primer (Bely and Wray 2004; see also the Appendix). PCR reactions were conducted with the GenAmp PCR System 9700 (Applied Biosystems) using Ex Taq Kit (TaKaRa) under the following conditions: 35 cycles, denaturation at $96{ }^{\circ} \mathrm{C}$ for $5 \mathrm{~min}$, annealing at $46{ }^{\circ} \mathrm{C}$ for $45 \mathrm{sec}$ and extension at $72{ }^{\circ} \mathrm{C}$ for $1 \mathrm{~min}$. The reaction mix (total reaction volume was $50 \mu \mathrm{l}$ ) included: $36.75 \mu \mathrm{l}$ of $\mathrm{H}_{2} \mathrm{O}, 5 \mu \mathrm{l}$ of $10 \mathrm{x}$ Buffer, $4 \mu \mathrm{l}$ of $10 \mathrm{mM}$ dNTP, $1 \mu \mathrm{l}$ of each $5 \mu \mathrm{M}$ primer, $0.25 \mu \mathrm{l}$ of ExTaq $5 \mathrm{U} / \mu \mathrm{l}, 2 \mu \mathrm{l}$ of DNA template. The PCR products were separated by TBE gel electrophoresis in 1.5\% agarose gel and visualized under UV after staining with ethidium bromide before being purified with 'Gel and PCR Clean-up DNA purification kit' (Promega) following the manufacturer's protocol. Amplification products were sequenced in both directions, using the same primers as in PCR. Sequencing reactions were done using BigDye Terminator v3 Cycle Sequencing Kit (Applied Biosystems). Each reaction contained $0.5 \mu \mathrm{l}$ of primer, $1 \mu \mathrm{l}$ of BigDye, 16 $\mu \mathrm{l}$ of $\mathrm{H}_{2} \mathrm{O}, 1.5 \mu \mathrm{l}$ of $5 \mathrm{X}$ BigDye buffer, and $1 \mu \mathrm{l}$ of DNA (total reaction volume was $20 \mu \mathrm{l})$. Reactions $\left(25 \mathrm{cycles}\right.$, denaturation at $96{ }^{\circ} \mathrm{C}$ for $10 \mathrm{sec}$, annealing at $50{ }^{\circ} \mathrm{C}$ for $5 \mathrm{sec}$, and extension at $60^{\circ} \mathrm{C}$ for $4 \mathrm{~min}$ ) were run on the GenAmp PCR System 9700 (Applied Biosystems). Amplified products were purified using the Performa ${ }^{\oplus}$ DTR Gel Filtration Cartridge kit (EdgeBio). Products of the sequencing reactions were read using ABI 3130 Genetic Analyzer (Applied Biosystems). Sequences were assembled and edited using SeqEd ver. 1.0.3 (Applied Biosystems Inc.), and these raw data are presented in an Appendix. 


\section{Morphological description}

The neotype was sketched using a Nikon SMZ-U binocular microscope with drawing tube, dissected, and described employing taxonomic conventions explained in Gates (1972) and Blakemore (1994, 2002, 2008a). Higher classification follows Michaelsen (1900) as modified by Blakemore (1994, 2000a, 2008a) rather than by Gates $(1959,1972)$ or Sims (1980).

\section{Taxonomic Results}

Phylum Annelida Lamarck, 1802

Class Oligochaeta Grube, 1850/Clitellata Michaelsen, 1919

Order Megadrili Benham, 1890/Haplotaxida Michaelsen, 1900

[Suborder MONILIGASTRIDA]

Family Moniligastridae Claus, 1880

Type-genus: Moniligaster Perrier, 1872.

Type-species: Moniligaster deshayesi Perrier, 1872 from Sri Lanka.

Family diagnosis: (from Michaelsen 1900: 109; Stephenson 1923: 116; Gates 1962: 299, 1972: 238; Blakemore 2008a): Setae lumbricine. Prostomium prolobous. Male pores one or two pairs (on 10 or in 10/11 or 11/12 and 12/13) behind spermathecal pores (in $7 / 8$ and/or 8/9) and in front of female pores (in 11/12 or near 12/13 or 13/14). Testis and male funnels intraseptal in sacs. Gizzards multiple (e.g. 2-12 in region of segments 11-34) behind ovarian segment. Nephridia holoic. Clitellum unilayered (one cell thick). Ova macrolecithal (i.e., with large yolk-particles). Spermathecae with long tubular ducts. Last hearts in segment 9.

Distribution: Southeastern and eastern Asia, from Sri Lanka to eastern Siberia, also Korea, Japan, the Philippines, Borneo and Sumatra. Several species of Drawida have been reported outside the generic range, some of these later synonymized, but most moniligastrids are probably confined to their areas of origin in the Indo-Asian region (Gates 1972).

Genus Drawida Michaelsen, 1900

Type-species: Moniligaster barwelli Beddard, 1886 from Manila, by original designation.

Genus diagnosis (amended slightly from Michaelsen, 1900: 114; Stephenson, 1923, 1930; Gates, 1962, 1972; Blakemore, 2002, 2008a): Small to giant [ 1,000 mm e.g. Drawida hattamimizu, D. grandis (Bourne, 1887)] terrestrial earthworms. Setae lumbricine [said to have a "smooth body without setae" in D. zhangetalia Blakemore, 2006 nom. nov. pro D. cheni Zhang et al., 2006 (non D. cheni Gates, 1935)]. Dorsal pores absent or intermittently present (e.g. in some D. barwelli, and cf. D. japonica RJB pers. obs.). Spermathecal pores 
at 7/8 (spermathecae without Y-shaped "dichotomously branched glands" of Moniligaster Perrier, 1872). Clitellum includes segments 10-13 but its exact extent often obscure. Male pores usually in or near 10/11 and female pores in or near 11/12. A pair of testes and male funnels typically in intraseptal sacs of 9/10. Short or sessile pseudo-prostates associated with male atria. Ovaries and oviducts typically in 11 with a pair of ovisacs extending posteriorly from septum 11/12. Last hearts in 9. Several, i.e., two to eight (or exceptionally nine in D. hattamimizu) moniliform intestinal gizzards within segments 11-27 [or 27-34 in D. nilamburensis (Bourne, 1894)]. Holoic (and sometimes vesiculate) with blood capillaries on the nephridia. Oesophageal gizzards, calciferous glands, and intestinal caeca absent.

Taxonomic Note: Gender of the name Drawida - after the 'Dravidians' of Southern India/Sri Lanka - was not initially stated, but Easton (1984: 111), citing ICZN articles (now ICZN, 1999: Art. 30.1.4), proposed to continue its treatment as a Latinized feminine noun.

Distribution: Indo-Oriental region, very widespread: "Drawida has a self-acquired range which may only be exceeded by that of the Lumbricidae, and is larger than that of the Pheretima s. lat. domain, consequently it is expected to yield proportionately more species... Possibly, Drawida alone may prove to have the greater number of species" (Gates 1972: 238-239). However, currently only about 200 nominal taxa are known (cf. 670 holarctic Lumbricidae versus 940 or so valid species of oriental pheretimoids in the family Megascolecidae - Blakemore 2007a, 2008a). Described by Stephenson (1923: 118, 124, Chart 1) as "one of the large Indian genera", its centres of diversity appears to lie in Sri Lanka, southern India, the eastern Himalayas, and Myanmar. At least one supposed native, Drawida ghilarovi Gates, 1969 from Russia in south-east Siberia, is listed in the Red Data Book for that region (Anon. 1997). The type, Drawida barwelli, was first recorded as an exotic from Australia by Blakemore (1994, 1999), from China (Hainan) by Blakemore (2007a, 2008a), and is a new Japanese record as "D. cf. barwelli" in the present study (from Kurotsu and Inazu, Shiga-ken - Biwako samples 4 and 5, collected from rice paddies, 17.VI.2009 by RJB \& MJG). Relatively few species, apart from the cosmopoli$\tan$ D. barwelli, are peregrine: D. japonica (Michaelsen, 1892) has been reported from the western Indian Himalayas, Yunnan and Szechuan in China, Japan, and Korea, and is also found on Taiwan (also cf. D. ramnadana Michaelsen, 1907 from south India), but Gates (1972) was of the opinion that some records of D. japonica outside Japan/ Korea were misidentifications. This latter possibility is briefly investigated herein as part of further studies (Blakemore in prep.) on its relationship with $D$. barwelli proper.

Species Drawida hattamimizu Hatai, 1930

Figs 1-3

Synonymy:

Drawida hattamimizu Hatai, 1930: 485, figs 1-7; 1931: 85-98, fig. 6; Ohfuchi, 1938b: 395; Yuki, 1940a: 20?, b: 12; Kobayashi, 1941: 263; Ogawa, 1944: 81, fig. 30; Easton, 1981: 35, 37, 38, tab. 1; Uchida, 1988: 546; Blakemore, 2003; 2004; 
2006; 2007a,b; Watanabe, 2005 (figs 1-5); Kamihira, 2005 (map fig. 1); Nishino, 2006: 542; Anon. 2009 (photos).

Drawida hattaminizu; (laps.) Reynolds \& Cook, 1976: 111.

\section{Etymology: Japanese - "Hatta earthworm".}

Material inspected: LBM1380000078: Neotype. From mud and embankments of rice paddies at Hatta-cho (ca. $36^{\circ} 38^{\prime} \mathrm{N} 136^{\circ} 41^{\prime} \mathrm{E}$ ), Kanazawa-shi, Ishikawa-ken; 21.VIII.2002; collected by R.J. Blakemore (YNU E.S.S.); preserved in $85 \% \mathrm{EtOH}$ (as figured and dissected here) with small samples of body wall around segment 300 taken for testing in 2004 (unsuccessful), another tissue sample from around segment 350 taken in 2009 (also unsuccessful) together with a final sample from near segment 250 (successful DNA analysis as reported herein). Neotype newly designated.

Other material inspected: a cocoon (LBM1380000079) collected at same time as the neotype (by RJB, see Fig. 1). Also seven sub-adult/mature specimens from Kaideima-cho, Hikone-shi (ca. $\left.35^{\circ} 14^{\prime} \mathrm{N} 135^{\circ} 16^{\prime} \mathrm{E}\right)$ Shiga-ken in rice paddy fields near the University of Shiga Prefecture's campus (Dr Misako Urabe's and Yuko Goto's sites); collected 18.VI.2009 by RJB, MJG, M. Urabe \& Y. Goto; four preserved in $85 \%$ ethanol (LBM1380000083 one posterior regenerate semi-mature specimen also dissected); three other specimens in $99.5 \% \mathrm{EtOH}$ for DNA comparison (LBM1380000084). Further LBM specimens collected by Kei Tanikawa on 10.IX.2008 from Hatta-cho, Kanazawashi, Ishikawa-ken used alive for a public exhibition display (LBM1380000081-2); and on 4.IX.2008 from Asazumachikuma, Maibara-shi, Shiga-ken (LBM1380000080). Plus a single, paler immature D. hattamimizu collected at Mano-ono 2-chome, Otsushi, Shiga-ken on 15.V.2009 by Y. Kusuoka (LBM1380000088).

Description (of neotype compared to descriptions by Hatai, Easton, etc.):

External characters: Length of preserved neotype ca. $400 \mathrm{~mm}$, other specimens stretching up to ca. $1,000 \mathrm{~mm}$ in life but averaging $246 \mathrm{~mm}$. Hatai 1930) by $9-10$ $\mathrm{mm}$ wide. Segments ca. 400 (cf. average of 317, Hatai 1930); anterior segments stout and triannulate around genital region (Fig. 2). Colour dark blue-black, although ventrum appears paler, almost pinkish in alcohol; clitellum darker or obscure in life but becomes ash-grey on preservation in alcohol. Less mature worms may be brick-red in colour or paler. Prostomium prolobous. Setae minute and very closely paired (setal ratio as shown in Fig. 1); viewed perpendicularly appearing dark from the worm's viscera but are actually translucent when viewed from the side; genital setae not found. Dorsal pores absent. Nephropores not found (possibly minute and lateral in $\mathrm{d}$ lines as per Hatai?). Clitellum in 9,10-15,16 (ca. $1 / 29-1 / 215$ in neotype), perhaps slightly more saddle-shaped than annular as setae cd seem occluded and the dorsum rugose. Genital markings as smallish tumescences paired just posterio-median to setae a on 6-9, sometimes in 10 but usually not, and on 11-12,13 (those in 13 missing from neotype but present in Hikone specimen); secondary, smaller pair seen in neotype on 7 in position of setae d (figured); one or more, or all, markings may be absent (maturity?). Spermathecal pores lateral to raised mounds in $7 / 8$ at or slightly median to setae c (cf. Hatai who claims the pores are on the "on the tip of the prominent papillae", and Easton who 


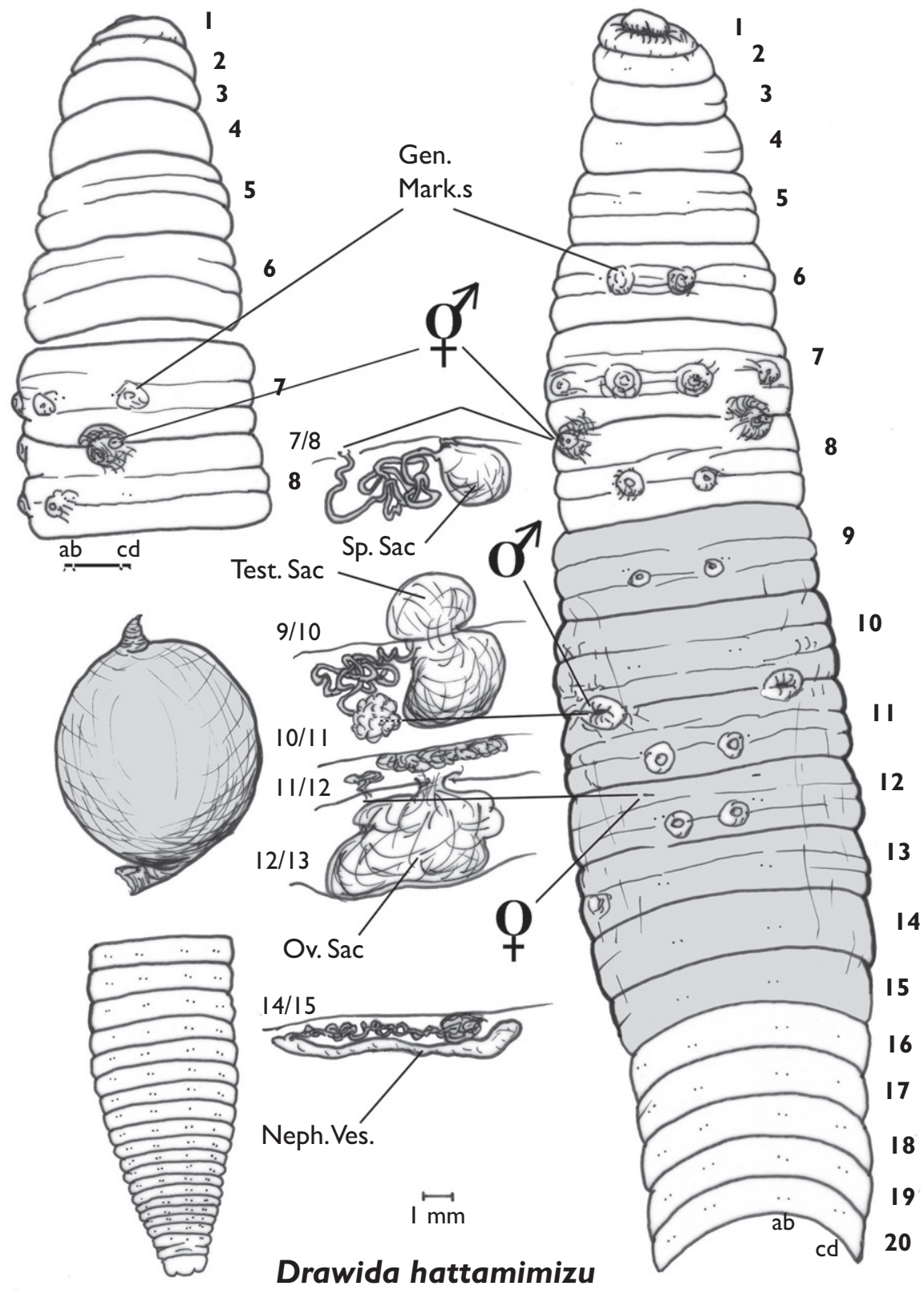

(C) RJB 2009

Figure I. Drawida hattamimizu, Neotype showing dorsal view of anterior (prolobous prostomium and no dorsal pores); a rotated dorsolateral view showing spermathecal pores in 7/8; a cocoon (shaded); ventral view of posterior; spermathecae in 8 , male organs in 9-10; female organs in 11-12; a nephridium in 15; and details of anterior ventrum with segments numbered and pores labeled. The clitellum is shaded to its fullest extent (in life the whole body is dark coloured with the clitellum only slightly darker). 
has them "ventral to d"). Male pores in large slits in 10/11 just ventral of position of (occluded) setal cd lines; when protruded appearing small and superficial on summits of rounded porophores that are not construed as penes. Female pores as paired slits on 12 approximately in setal $b$ lines just posterior of intersegment 11/12.

Internal anatomy: Cerebral ganglia in segment 2 originating from ventral nerve cord. Pharyngeal mass with numerous tendons up to segment 5 (i.e., to septum 5/6). Septa 5/6-9/10 thinning slightly, 10/11-11/12 also thin but enclosing ovarian segment; thereafter becoming membranous; septa in segment 12 distended by paired ovisacs. Blood vessels: dorsal large, single; ventral vessel narrower; long concertinaed hearts paired on either side of oesophagus in 6-9. Oesophagus long and narrow to 12 the latter half of which sometimes modified. True gizzards in 13-18 (i.e., six in neotype and in typical specimens described by Hatai), less often with up to nine or nine-and-a-half in $1 / 212$, 13-20, 21 (Hatai); becoming increasingly muscular posteriorly. Intestine origin in 19 (neotype) or in segment after the last gizzard, with initial two segments "narrow tubular" (Hatai). Calciferous glands, typhlosole and intestinal caeca absent. Spermathecal ampulla as simple sacs distended by white flocculent (seminal) material and attached anteriorly to septum $7 / 8$ in 8 , with convoluted duct to a simple, small spermathecal chamber in $7 / 8$. Testes paired with each male funnel enclosed in intraseptal testis sacs of 9/10 (acting as seminal vesicles) bulging into both 9 and 10 . Vasa deferentia emerging from septum $9 / 10$, long and convoluted and entering body wall near position in 10/11 of male pores, these latter overlain by sessile prostate glands (male atrium small). Ovaries as paired glandular attachments anteriorly in segment 11 on septum 10/11, with oviducts posteriorly transgressing septum 11/12 to female pores in 12. Large paired ovisacs, gravid with masses of relatively large orange-coloured eggs, filling segments 12 , displacing septum $12 / 13$, and sometimes extending further back to 13/14 (Hatai). Sessile glands correspond in position to external manifestations of genital markings (thus probably they exude some secretions from these markings). Nephridia large, holoic from 3 (Hatai) or 4 (neotype, but those in 3 perhaps small and overlooked in pharyngeal mass), absent from 10 (or vestigial and lost in vasa deferentia in neotype and Hikone specimen); vesiculate with elongate, sausage-shaped bladders and fatty deposits to the tubules (in some segments of neotype)

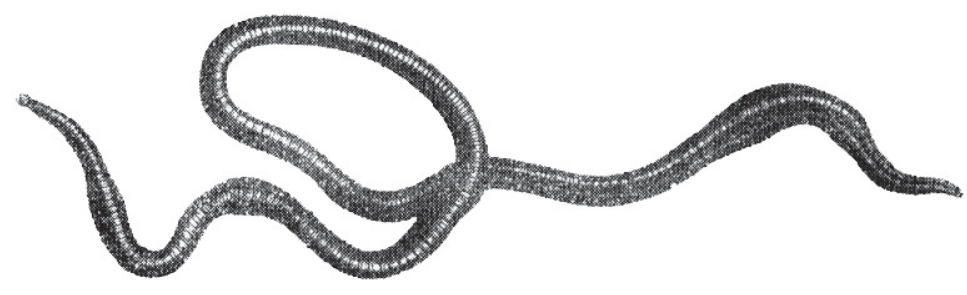

Figure 2. D. hattamimizu unscaled habitus (from Watanabe, 2005, fig. 1 after Hatai's 1931 original). 


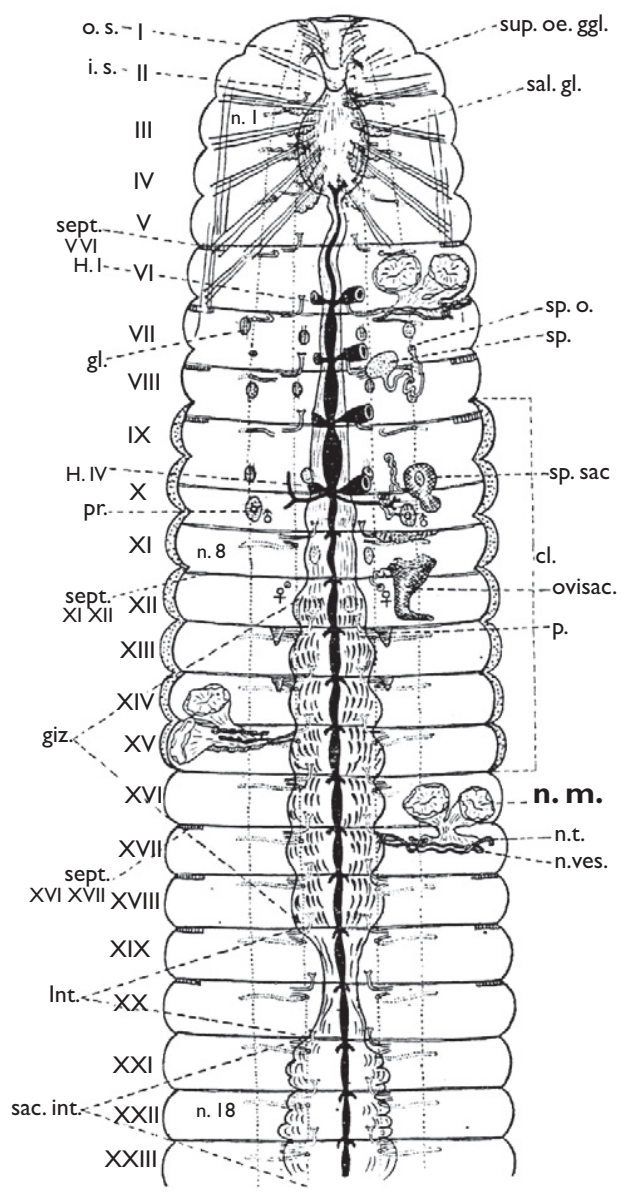

Figure 3. D. hattamimizu detailed internal anatomy showing the disputed paired nephridial funnels (“n.m.") sketched for only three of the nephridia (after Hatai, 1930: fig. 4).

in other segments they have more noticeable convoluted mesentery. Nephridia supplied with blood capillaries (Hatai and RJB pers. obs. in neotype) as is definitive of Megadrili.

Ingesta: Organic paddy mud with plant fibres, including root hairs, and few grits.

Cocoon: With same collection details as neotype and commensurate with the clitellum (Fig. 1), a large, turgid sphere with tapering or tubular processes at its poles; the body wall is thin and transparent suggesting nutrients are supplied internally (from unfertilized eggs?); cf. Ohfuchi (1938b).

Behaviour: Semi-aquatic; casting activity takes place at least partly on surface; constructs burrows approximating to worm's body width; moves rapidly though these burrows but becomes docile when handled and can easily be extended by hand (to ca. 600 or $1,000 \mathrm{~mm}$ without damage). Posterior regenerates found (RJB pers. obs.) 
and Hatai wrote that damaged worm survival was "astonishing". No details yet known of breeding habits of this species, but location of the genital markings (GMs) would align perfectly in amphimictic concopulants, those in 6 and 7 opposing those in 12 and 11 , and 9 to 9 mutually co-incident, thereby locating the male pores precisely over the spermathecal pores. Outer markings in 7 and those in 8 may be unilateral 'sperm blockers'/suckers. Associated GM glands possibly provide adhesives, and/or other exudates to help sterilize and exclude parasites (such as microbes, protozoa, or nematodes) during sperm transfer. Despite their protrusion in the preserved neotype (Fig. 1), it is unlikely that the spermathecal mounds intrude into male openings pouches during sperm exchange, rather than vice versa as would be expected.

Distribution: Japan, Honshu, ISHIKAWA-KEN (Hatai 1930; Kobayashi 1941; Easton 1981; Watanabe 2005; and RJB pers. obs.) Hatta-mura (village), now Hattacho, Kanazawa-shi (ca. 36 $38^{\circ} \mathrm{N} 136^{\circ} 41^{\prime} \mathrm{E}$ ) in the embankments of rice paddies and in adjacent parts of Kanazawa city alongside Kahoku Lake (ca. 36 $34^{\circ} \mathrm{N} 136^{\circ} 39^{\prime} \mathrm{E}$ ); Chubu-Chiho (Kanazawa) (Kobayashi 1941); SHIGA-KEN (Hatai 1931: 90?; Yuki 1940a?, b; Kobayashi 1941; Easton 1981; Watanabe 2005; and RJB pers. obs.) Lake Biwa (ca. $35^{\circ} 20^{\prime} \mathrm{N} 136^{\circ} 10^{\prime} \mathrm{E}$ ) on the western and eastern shores in restricted locations; Kinki-Chiho (Shiga) (Kobayashi, 1941); FUKUI-KEN found by Makoto Uenishi (in litt., 9.XII.2009) at Mikata-ko, one of Five Lakes of Mikata near the Sea of Japan northwest of Lake Biwa. Watanabe (2005) argued that Easton's inclusion of HOKKAIDO, Ishikai (near Sapporo) from the report by Ohfuchi (1938a: 23, 24) was a mistake as Ohfuchi only listed it as an aquatic species occurring in Japan, i.e., not from Hokkaido. Hatai (1930) could not find it in other districts for ca. $80 \mathrm{~km}$ around Kahoku Lake in Ishikawa Prefecture and thought it an exotic species to Japan, from "some Eastern tropical lands", possibly introduced following Asiatic voyages of local merchant explorer Gohei Zeniya who died in 1852. Its distribution around Lake Biwa also appears somewhat patchy and restricted (Blakemore 2007b and vide supra) without noticeable barriers, as is characteristic for a species relatively recently introduced.

Conservation status: The Red Data Book of Japan lists D. hattamimizu as endangered and "quasi-extinct" (Anon. 2007), that of Ishikawa Prefecture lists it as Endangered - Level I (Anon. 2009), and that of Shiga Prefecture lists it as an insufficiently documented species (Nishino 2006).

Habitat: Almost always associated with rice paddies and banks and ditches of ponds/lakes.

Species associations: Other earthworms at the Hatta type locality were not investigated, although Hatai (1930: 506) noted D. hattamimizu abundance to the exclusion of other worms, despite his later description of Metaphire yamadai (Hatai, 1930) from the same location. Specimens (pers. obs. RJB) found at Hikone paddy rice fields leased to Shiga Prefectural University were of these species: Drawida japonica (Michaelsen, 1892) that also compares with D. barwelli, Helodrilus hachiojii Blakemore, 2007, Amynthas hupeiensis (Michaelsen, 1895), Amynthas robustus (Perrier, 1872) and some miscellaneous Amynthas/Metaphire spp. immatures. A large $(-10 \mathrm{~cm})$ black leech (unidentified Hirudinea) was also present at the site. [Note that Eukerria saltensis (Beddard, 
1895) was not found during this brief survey; however fine grandular casts looking similar to those it produces in other local paddies were seen around some fields]. All specimens are labeled and deposited in the LBM collection as part of Accession No. 'Misc. Invert.' FY2009-13.

Endosymbionts/Parasites/Predators: None neither observed nor yet recorded except possibly the black leech found on site at Lake Biwa.

Pharmacology: Drawida hattamimizu is one of the species listed as providing a powdered extract therapeutic medicament for the treatment of thrombosis and in antihyperlipemic, antidiabetic, antihypertensive and antihypotensive preparations under US Patent Nos. 5186944 and 5024844 by Ishii et al. (1991 - http://www.freepatentsonline.com/5186944.html/ http://www.freepatentsonline.com/5024844.pdf).

Ecological and economic importance: Hatai (1930) wrote that this species was being used by the local fisherman as live bait for eel fishing in Ishikawa. He also thought its many anatomical virtues made it an ideal subject for physiological investigation. Yuki (1940a, b) mentioned that fishermen in Shiga-ken, where Lake Biwa is situated, also using a worm that he identified as D. hattamimizu to catch 'gigi', Pelteobagrus nudiceps (Sauvage, 1883) - a type of freshwater catfish. This earthworm's current distribution has been restricted by voluntary transportation controls imposed by farmers who consider it a threat to paddy embankments and bunds (Hatai 1930; Watanabe 2005). Hatai was told by farmers that burrows of $D$. hattamimizu were "finger-sized" and drained the raised paddy fields; however, the burrow widths observed during the current work were all less than $1 \mathrm{~cm}$. Larger crayfish burrows were seen in paddy embankments at Lake Biwa, which may easily be mistaken for large worm holes, as happened with Megascolides australis McCoy, 1878 that was also at one time thought, erroneously, to construct chimneyed freshwater crayfish ('yabbies' = Engaeus sp.) hollows (vanPraagh 1992). Watanabe (2005) described and photographed small granular casts of $D$. hattamimizu in a harvested rice paddy, but larger ribbon casts - like toothpaste squeezed from a tube - were seen to be deposited in the burrows as the worms attempted to escape capture (RJB, pers. obs.). Watanabe (2005) further reports this species is still used extensively in Ishikawa by the local eel fishermen as bait, and he advocates its local conservation.

Remarks: The current report augments the original. Differences in the neotype from the original description by Hatai (1930) are that his specimens sometimes had an extra pair of markings in 13 (as observed in some specimens described herein) and that a smaller pair of markings was newly found in segment 7. Further, Hatai (1930) said that internal glands were present even if the external markings were absent, but in the neotype no such (non-functional?) internal glands were seen in segment 13 where markings would be expected. This character may thus be variable. Moreover, his detailed description of the nephridia is not wholly supported in the neotype and other specimens inspected inasmuch as the two membranous preseptal umbrella-like funnels he claimed to observe from each nephridium are not found (cf. Fig. 3). Perhaps Hatai interpreted the extensive mesentery on the nephridial tubules as being funnel-shaped and this misconception was enhanced in his artist's figures. Hatai (1930) reported the nephridia in 9 and 11 as being vestigial or absent whereas they are present in the neotype (and 
in other specimens), and he reported nephridia in 10 as being present, whereas they are aborted (or vestigial and implicated within the convoluted vasa deferentia) in the current specimens. The forms and exact locations of the male and spermathecal pores are now brought into their proper relationships. In all other regards, the descriptions (including behaviours and locations) unequivocally confirm the neotype as belonging to the same species, from the same type locality, as that originally described nearly 80 years ago by Hatai (1930). Marker character queries from Easton (1981: tab. 1) and his other morphological and distributional mistakes from 30 years ago are now resolved.

\section{DNA Results (raw data in Appendix)}

Current COI sequences are reported online with CBOL's Internet GenBank facility with Accession Nos. GQ500899-GQ500902 - this the first ever for a described earthworm type specimen. The sequences of the neotype and a topotype agree $100 \%$, whereas nucleotide bases of a $D$. hattamimizu specimen from Hikone near Lake Biwa differ from these by ca. $1.14 \%$. Since this difference is only slight, the specimens are confirmed as conspecific despite the limited sample. This is the first known sequence for $D$. hattamimizu so, as expected, no correspondence was found from other Internet DNA/RNA sequence searches.

The COI nucleotide sequence of a specimen of Drawida cf. japonica also from the Hikone site concurs with corresponding sequences of Drawida japonica japonica vouchers in GenBank by ca. $82.87 \%$. But, as this represents a concomitant difference of $17.13 \%$, their mutual conspecificity may be questioned (data in Appendix).

\section{Discussion}

The overriding Principle of Typification (ICZN 1999: Art. 61) provides for "the objective standard of reference" of a nominal species, further stating that: "No matter how the boundaries of a taxonomic taxon may vary in the opinion of zoologists the valid name of such a taxon is determined from the name-bearing type $(s) .$. . Hence there is a need for DNA sequence analyses aimed at helping resolve taxonomic ambiguities in earthworm systematics to be solidly based on types. This has been recognized for many years in the routine preservation of both types and voucher specimens, e.g. those in the Earthworm Collection of the Australian National Insect Collection (ANIC), in 85\% EtOH ethanol rather than DNA-disruptive formalin (Blakemore 1994; 1995; 2000a).

In the current work, the historical literature and morphological data have been combined with modern molecular information for the first time for an earthworm having an indisputably correct scientific species name. Moreover, Drawida hattamimizu Hatai, 1930 usually occurs at the head of national species lists of Japanese earthworms that are systematically ordered by taxa (Drawida being one of the more primitive megadriles) and alphabetically (e.g. Easton 1981: 35; Blakemore 2004, 2005, 2007a). 
As such, it sets a precedent for progressively DNA barcoding all the valid species of Japanese earthworms from their types, and, where expedient, from the types of their purported junior synonyms. It is here recommended that any future 'new' earthworm taxa named under ICZN from this country, or elsewhere, be simultaneously treated for such unambiguous CBOL barcodes to meet current genetic/informatic standards.

\section{Neotypification}

Although neotypification in the absence of a name-bearing type is non-routine under the current Code (ICZN 1999: Art. 75), this mechanism allows a name and its hypothetical species concept to be defined objectively and tied permanently to a tangible specimen from which DNA can be extracted. At the same time, the aim of DNA barcoding without some ultimate reference is ungrounded. It is thus necessary at some stage for molecular data to objectively refer to the name-bearing type of a taxon. The unambiguous ideal, as herein, is to sequence directly from a type. Qualifying conditions of ICZN (1999: Art. 75.3) are that: "A neotype is validly designated when there is an exceptional need and only when that need is stated expressly and when the designation is published with the following particulars...". The required particulars, in this case, are:

Exceptional need: The principal justification for neotypification of Drawida hattamimizu is the unique opportunity, nearly 80 years after its description, to meet ICZN qualifying conditions by collecting specimens from the type locality and to simultaneously provide morphological and molecular definitions that will leave no question about its identity or taxonomic status. It is designated with the express purpose of clarifying the taxonomic status. Thirty years ago, Easton (1981:37) raised doubt on all Japanese Drawida when he wrote: "None of the eight species considered here is particularly well known and the specific status of each requires closer investigation." Also in his Table 1 of Marker Characters he has "?"s for D. hattamimizu and notes some of its other features that were poorly defined until now (e.g. forms and locations of the male and spermathecal pores). These doubts about its specific status, plus other omissions or errors in Hatai's original description are now reconciled through dissection and inspection of the neotype. Easton's (1981) mistaken listing of D. hattamimizu from Hokkaido has already been mentioned. Hatai (1930) had thought it an introduced species due partly to its restricted distribution in Ishikawa Prefecture. The subsequent finds do not fully refute this, and specimens from the Lake Biwa population conform to its specific identity, despite initial uncertainty (Yuki 1940a). Conspecificity was confirmed partly on barcode comparison with the neotype despite their being evidence of slight genetic drift (vide supra). Although Drawida hattamimizu appears well recognizable and its identity in Japan is now no longer in any doubt, the designation of a neotype is a practical necessity for the sake of anchoring its DNA (e.g. COI barcode) that will henceforth play a major rôle in identifying specimens of this species, genus and family. The neotype and its associated COI barcode will likely come into play in recognizing whether this species has been unearthed in its land(s) of origin, while also distinguishing it from any congeners there. This study is a first step to- 
wards the eventual taxonomic clarification, via DNA-based differentiation, of the Moniligastridae which is a notoriously difficult group to work on. In particular, the genus Drawida with its many small, similar looking and often misdescribed taxa - not least its type-species D. barwelli and its numerous synonyms as detailed by Blakemore (1994, 2008a) - requires discrimination. Thus D. hattamimizu Hatai, 1930 is offered as a start unto itself with the doubt about its identity in Japan raised by Easton now resolved and, moreover, by its being the first example of a single earthworm taxon removed from a real and pressing "complex zoological problem": that of objectively reconciling nomenclature, specimen identity, species boundaries and barcode genomics (vide infra). This complex zoological problem is especially acute and chronic for earthworm taxonomy in Japan, for reasons already mentioned in the Introduction above.

Differentiating characters and consistency with the original description: The data and description (morphology, ecology, behaviour) of the neotype herein complies tolerably with the original detailed description by Hatai (1930) except, most notably, some details of the nephridia, genital pores, and genital markings. Moreover, its morphological features confirm this taxon in Drawida, although Hatai (1930) initially thought it had some resemblance to Eupolygaster Michaelsen, 1900 (nom. nov. pro Polygaster Horst, 1896) as then defined. Characters that differentiate Drawida hattamimizu from its known congeners in Drawida are its unusual large size and dark colouration, the extent of its clitellum, its distinctively pronounced genital markings along with its polygiceriate arrangement - all now combined with its genomic COI profile.

Specimen recognition: The LBM and GenBank registration data, collection data, and morphological description provided herein ensure recognition of the unique specimen designated as the neotype of $D$. hattamimizu.

Confirmation of loss of original type specimens: Hatai failed to routinely typify his new species. No types were explicitly designated in Hatai's (1930) original description of $D$. hattamimizu despite the description being based on "many specimens". These specimens were thus all syntypes, but none is known to still exist. The same situation pertains to all other historical Japanese earthworm types that were not deposited in European institutions, e.g., those species poorly described by Goto and Hatai (1898, 1899). Type material of $D$. hattamimizu has not been reported by any prior authority who has mentioned this taxon (as listed in the synonymy above), including the catalogue by Reynolds and Cook (1976), and it is omitted from the limited JTYPES (2009) facility. Hatai was the first Professor of Biology at Tohoku University in Sendai, but our inquiries to the Department of Biology there (Dr. Jotaru Urabe) and to the Tohoku University Museum (Dr. Jun Nemoto) regarding his earthworms were fruitless: none are preserved there. The suggestion was made, however, to check the Saito Ho-on Kai Museum of Natural History in Sendai, inasmuch as Hatai's collecting trip to Hatta and other work was supported by funding from the Saito Ho-on Kai several years before the museum opened, and Hatai later published on other earthworms in that museum's journal. In 2006 all the collections of the Saito Ho-on Kai Museum were transferred to the National Museum of Nature and Science in Tokyo, where the cataloguing of the over 1,200 earthworm specmens has nearly been completed by Dr. Toshiaki Kuramo- 
chi who found no specimens labeled as Drawida hattamimizu. This was confirmed from personal enquiries and inspections by RJB and MJG in 2009/2010. Also, the only specimen clearly from Hatta is labeled as "Pheretima acincta (Goto and Hatai)" (= Metaphire acincta). Thus we firmly conclude that syntype material of $D$. hattamimizu no longer exists.

Proximity to type locality, and suitability of depository: The neotype is from the stated type locality and is deposited in a research institution with proper facilities and accessibility, viz. the Lake Biwa Museum in Kusatsu, Shiga Prefecture, Japan. Also, the DNA sequence data is freely available via BCOL website (GenBank).

Reiterating the main consideration, this study is the first known instance of DNA analysis and barcoding of an earthworm type specimen, as all other published molecular works (at species, genus and family levels) appear based on voucher specimens that are unfixed to the types of the specific names claimed and as such do not strictly comply with ICZN nomenclature. It is anticipated for future mandatory DNA barcoding, using prevailing technologies that are nevertheless expected to develop rapidly, of all new types and of all previously known taxa so that exhaustive and accurate biodiversity inventories and species identification libraries (e.g. that of the Barcode of Life Data Systems - BOLD 2010) may be compiled, despite the numerous obstacles such fledgling work entails.

\section{DNA Barcoding}

Criticism of the current GenBank as a repository for DNA barcodes has been made by Pleijel et al. (2008), who were concerned about routine voucher source materials, and by Chang et al. (2009) who were more worried about names - but both missed the bigger issue of species types. These latter authors re-evaluated barcode use in earthworm identifications by, amongst others, Huang et al. (2007) and concluded: "The accuracy of species names is the basis of taxonomic and systematic studies. Certainly, the correct use of names is crucial for testing the ability of DNA barcoding as a tool to discriminate species. This fact might sound obvious, but several studies aiming to test DNA barcoding effciency have neglected this basic requirement." Huang et al. (2007) had several misnamed or misplaced taxa in their list of Chinese species (cf. species checklists and inventories in Blakemore 2003, 2006, 2007a).

In one specific case, Huang et al.'s study showed a remarkably consistent intraspecific sequence agreement of $100.00 \%$ for four specimen samples claimed as Drawida japonica japonica (GenBank Accession Nos. EF077597-EF077600 from Huang et al. vouchers). In the current limited study, a sequence from a Hikone specimen of Drawida cf. japonica, included only for general comparison, differs somewhat from those Genbank Drawida japonica japonica vouchers by $-17.13 \%$, thus conspecificity with these non-type Chinese specimens is not wholly supported. For resolution, further studies are required to check Japanese specimens against barcodes derived from D. japonica (syn-)types in Zoologisches Museum Hamburg (No. 403) and/ 
or the Museum für Naturkunde, Berlin (No. 2122), and the Chinese specimens, at least, require comparison with the types of synonymic Drawida grahami Gates, 1935 (Smithsonian Institution, USNM 20093), also with types of erstwhile sub-species Moniligaster bahamensis Beddard, 1893 and Drawida japonica siemsseni (Michaelsen, 1910) (Hamburg No. 6233) plus its likely new synonyms (Blakemore, in prep.) of D. propatula Gates, 1935: 449 from China and Drawida calebi Gates, 1945: 211 from India.

Moreover, if the supposedly distinctive but uneven genital markings of $D$. japonica eventually prove to be parasitic artefacts (e.g. in the Japanese material they appear similar to Monocystis sp. gregarine cysts - RJB, pers. obs.), then its synonymy with parts of a prior $D$. barwelli species-complex seems feasible. Further testing of Drawida relationships without molecular consideration of the types of the type-species $D$. barwelli (Beddard, 1896) (Natural History Museum, London BMNH:1904:10:5:522-3, 582, cf. Easton 1984: 112), plus those of its ten or more synonyms, is quite pointless.

Interminable debate (e.g. Chang et al. 2008) on "non-monophyly" and boundaries of megascolecid pheretimoid species in genera such as Amynthas Kinberg, 1867 and Metaphire Sims \& Easton, 1972 can be quelled by objective molecular analysis and comparison of the types of their respective type-species (Blakemore 2002, 2008c). Furthermore, the status of the families Ocnerodilidae, Acanthodrilidae, Exxidae, Octochaetidae, and Megascolecidae etc. can be unequivocally determined only with reference to the characteristics, including the DNA, of the definitive types of the type-species of their type-genera (Blakemore 2005, 2008b) rather than piecemeal from random putative constituents.

\section{ICZN Nomenclature vs. molecular diversity and "Cryptic" or "Provision- al" species}

Following the basic biological convention of binomial Linnaean scientific naming that has evolved over the past 250 years, the formulation and application of a taxon's name from sub-species to super-family level must strictly comply with the current edition of an International Code (ICZN 1999). Strains, morphs, varieties, ecotypes, haplotypes, avatars and other infrasubspecific entities are unrecognized by ICZN, as are higher theoretical classifications. In contrast, each valid taxon name is grounded under the Principle of Typification to a representative specimen - the Type - under a further Principle of Priority. Such nomenclatural considerations are only slightly more complex when parthenogenesis occurs, and this is common to many of the cosmopolitan earthworm species, whereby all the variously degraded morphs belong under the first valid and available name, regardless if originally applied to the amphimitic (i.e. sexual) form, where this is found to exist, or to some parthenogenetic form. Under ICZN (1999: Art. 72.5.1) an animal, whether mature or not, or any part of an animal, even as little as a fragmentary trace fossil, or just the nucleus of an embryo from a cocoon are eligible to provide the type. Thus all varieties of dogs are but a single taxon: 
Canis lupus familiaris Linnaeus, 1758 (typus amissus), but not all terrestrial worms are the same as Lumbricus terrestris Linnaeus, 1758 (neotype BMNH 1973:1:1).

In the UK, King et al. (2008) recently claimed to "open a can of worms" by reporting "unprecedented sympatric cryptic diversity within British lumbricid earthworms" in the form of molecular cryptic species and stated that this "has profound consequences for all areas of earthworm research." But they did not anchor their work with comparison to the types of any of the six or so species they claimed to study. Their conclusions, as with all previous (and current) molecular or DNA analyses of earthworms, are thus ungrounded. For example, they claimed that "Phylogenetic analyses of mitochondrial COI and $16 S$ genes showed the presence of five highly divergent lineages, suggesting the presence of multiple cryptic species within Allo. [i.e., Allolobophora] chlorotica", and "furthermore, detailed analysis of one common species - Allolobophora chlorotica - shows that it is made up of at least three species in Britain and one additional species in central Europe" (Anon. 2008). Intraspecific divergence was apparently set at between $12-14 \%$ (cf. $>10 \%$ by Rougerie et al. 2009: fig. 2) which may be too low for COI genes as compared, say, to $16 \mathrm{~S}$ or $18 \mathrm{~S}$ genes (e.g. Cech et al. 2005; Siddal et al. 2001). However, even if their multi-species conclusions are valid, it would nevertheless be no more than an interim parataxonomy which, according to Krell (2004), "does not fulfill the criteria of a scientific method". One could not identify or arbitrarily name any one of King et al.'s specimens or strains as "A. chlorotica" proper without checking against the types. This is because Allolobophora chlorotica chlorotica (Savigny, 1826), a name that is objectively tied under ICZN to its extant Paris type, has 17 known synonyms plus three or more sub-species (including one new synonym as fully listed by Blakemore 2007a, 2008a). Each of these synonyms, if valid and available for use, competes for priority requiring their types to be tested progressively under the constraints of ICZN Principle of Priority. Only if DNA sequences of the types of none of these 20 prior taxa complied with King et al.'s "cryptic species" may it be strictly appropriate, or even possible, to suggest which are already scientifically named and which are potentially truly new to science.

Moreover, to suggest, as these authors do, it necessary to consider which particular molecular lineage of $A$. chlorotica is being investigated in future studies, is not justified by evidence of any appreciable morphological, physiological nor ethological differences between any "strains" King et al. (2008) claim to have discovered. If resurrection of synonyms is not merited, then possibly these "cryptic species", at this particular level of genetic divergence, are analogous to ecotypes or to the botanical microspecies aggregate concept (Anon. 2010). Some components may represent a parthenogenetic species-complex, at least from continental Europe, where larger genetic distances are possible due to polyploidy and lack of back-crossing (Cs. Csuzdi pers. comm. to RJB). Alternatively, these findings may relate to mere ghosts of nuclear mitochondrial pseudogenes (numts) as discussed by Siddall et al. (2009).

Sims and Gerard $(1985,1999)$ said A. chorotica (only in UK?) is obligatory biparental; and they believed the colour dimorphs to be ecotypes with the nominal green-coloured phase in pastures and waterways while the unpigmented phase is from 
well-drained gardens and woodlands (e.g. Blakemore 2000b; Lowe and Butt 2007). Some reproductive separation of nominal A. chlorotica "green morphs" from one of its current synonyms, Enterion virescens Savigny, 1826 referred to as "pink morphs", was indicated by Lowe and Butt (2008), but this too needs to be confirmed against molecular evidence from its Paris type and the name-bearing types of all 20 synonyms and sub-species alluded to above. All the more so since Savigny's varietal name "virescens" in Latin suggests "tending to a green colour". Thus the taxonomic "can of worms" was already wide open well before King et al. (2008) added to the debate. Although a solution may depend on DNA profiling (with current or future methods), this technology needs to be combined with rigorous traditional and systematic ecotaxonomic study.

Taxonomic resolution also remains elusive, despite claims by Pérez-Losada et al. (2009), for boundaries of the Aporrectodea caliginosa (Savigny, 1826) species-complex sensu Blakemore (2002, 2007a; 2008a) with types of supposed component species as yet untested. Another detailed study by Briones et al. (2009) completely avoided types, thereby leaving most of the results invalid and serving to demonstrate the inherent weakness of failure to follow first principals. Surprisingly, Rougerie et al. (2009: 798, fig. 1) intentionally advocate such disassociation of specimen barcodes from the essential barcode of the "Holotype" of a named species.

Similar reports variously claiming to differentiate iconic Eisenia fetida fetida (Savigny, 1826) from E. fetida andrei Bouché, 1972 - this latter being cited as either a synonym, morph, variety, sub-species, or as a separate species - have never been satisfactorily proven because their relevant types have not been sequenced. Supposedly recorded from low $\mathrm{pH}$ composts and laboratory cultures of $E$. fetida, E. andrei differs imperceptibly as specimens vary in their colouration (e.g. Sims and Gerard 1999). [Moreover, the Eisenia nordenskioldi (Eisen, 1879) species-complex is implicated, at least in part - see Blakemore (2008a)]. The two entities are alleged to represent molecular taxa that can surely be differentiated only by enzymic gel electrophoresis (Jaenike 1982), but this too requires confirmation from types of both nominal taxa. Unfortunately, the starting point for Jaenike's definitive study was a greenhouse population maintained by Dr Roy Hartenstein at the SUNY Syracuse campus from founding stocks initially procured from a number of bait dealers obtained from "all over", and supposed to consist of striped ("foetida") and unstriped ("andrei") vouchers that were deposited in the American Museum of Natural History. Øien and Stenersen (1984) later obtained similar electrophoretic results, but their taxonomy was somewhat confused and was equally ungrounded.

Dominguez et al. (2005) claimed to have demonstrated "reproductive isolation between $\mathrm{E}$. andrei and $\mathrm{E}$. fetida; they can therefore be considered distinct biological species." However, these authors failed to consider polyploidy, and the starting point for this study was Spanish and Brazilian populations, far removed from the type localities, that were differentiated neither by molecular/electrophoretic nor morphological analysis - presumably only striped or non-striped superficial colouration was used as the determinant. It should be stressed that colouration in earthworms, 
although manifestly obvious in live specimens, is a notoriously unreliable character for morpho-taxonomic determination due partly to influence of age, habitat and diet. At some stage, dissection or sectioning and microscopy is required (Gates 1972; Sims and Gerard 1985, 1999; Blakemore 2002, 2008a).

In actuality, Eisenia andrei may yield taxonomic priority to one or more of about a dozen other junior synonyms of $E$. fetida. Moreover, it is possible that multiple additional E. fetida "varieties" are involved (as indicated by Pérez-Losada et al. 2005). However, since no morphological or molecular analysis of type material of any one of the E. fetida species-group prioritized synonyms has been attempted, claims of correct taxonomic assignment are inconclusive (see Blakemore 2007a, 2008a for synonymy and discussion).

In another example, Cech et al. (2005: 95) deduced that recent molecular analysis of "Eisenia andrei ... is most likely a misidentification error and actually Erseus \& Kallersjo (2004) used in their analysis a specimen of Dd. subrubicundus" - but this identity too must be regarded as speculative without genetic comparison with the latter's types deposited in Turin.

Definitive results would not be quite as important for European regional taxa alone, were it not for the fact that those species mentioned above-and several of them are generic types-occur as cosmopolitans in places as distantly spread as Japan, Taiwan, New Zealand, Tasmania and Chile (Blakemore 2007a, 2008a, 2009), for example, and thus any nomenclatural implications have profound ripples worldwide.

\section{Summary conclusions}

As a relatively new science, molecular or genomic taxonomy has considerable scope for rapid development, there being both a technology lag and a taxonomic impediment. It is likely that some claims of species divergence are premature, especially where no attempt has been made to link the genetic information to any morphological or behavioural characteristics of the putative "cryptic" or "provisional" species vouchers except via their interim names.

Realistically, genetic studies and their future derivatives are the only hope to resolve some of the inherited nomenclatural impasses, notwithstanding taxonomic rigour as a prerequisite. Interestingly, Rougerie et al. (2009: 798), who preferentially advocate "Molecular Operational Taxonomic Units (MOTUs)" and surrogate vouchers, seem to further misconstrue the current ICZN concepts of synonyms, types and neotypification when they write: "In any case, the use of DNA to re-evaluate diagnostic morphological characters may allow a robust assignment of recently collected specimens to an ancient type using morphology, or alternatively, in these groups where overlooked cryptic species may be very frequent, the recourse to designation of neotypes for which DNA data are available might be the safest and most efficient way to proceed."

Museum shelves the world over are already stacked with vouchers and unsorted survey collections awaiting nomenclatural evaluation by overtaxed and often underresourced curatorial specialists. The definitive solution requires a coupling, once and 
for always, of each named species' types directly and expeditiously to their DNA profiles so that specimen identification in the field, or at the laboratory workbench, is autonomous - irrespective of morphological diagnoses - and the remaining specialist taxonomist's workload is unburdened. Indeed it would be obviously most sensible and efficient to at least seek competent taxonomic consultation before attempting any definitive phylogenetic study for a scientifically named earthworm taxon or, for that matter, any biodiversity survey or molecular systematics project, rather than to defer or to retrospectively delegate this responsibility. The first choice must be careful selection of proper reference specimens, ideally the types to which names are permanently attached, not merely to temporary OTU voucher surrogates which, as in the case of King et al.'s (2008) proposed cryptic lineage vouchers, seem ineligible to qualify as any sort of "neotypes".

It is hoped the present work will serve as a model for the kind of linkage of morphological species delimitation to DNA sequences and to ICZN name-bearing types that will, ultimately, be required to revive earthworm taxonomy and phylogeny and to realize all the benefits promised by the addition of molecular information to help define an earthworm species and its ecological interactions for both specialists and non-specialists.

A comprehensive world-wide, type-based resolution of these complex zoological issues in terrestrial earthworm nomenclature and genomic systematics - for all 6,000 nominal taxa - is essential and urgent, especially in this UN 'International Year of Biodiversity'. Sadly, no more than a simple start for just a single, relatively uncomplicated, species from a rice field in Japan is within the present scope and resources.

\section{Acknowledgements}

All taxonomic descriptions and conclusions presented here are by the first author (RJB). Laboratory, library and curatorial facilities were provided for a week at the Lake Biwa Museum by MJG; travel on that occasion was funded by LBM Comprehensive Research Project S06-02. All DNA sequences were run by EKK and her part of this study was partly supported by Japan Society for the Promotion of Science Invitation Fellowship (JSPS No. S42300038) and a KAKENHI (20008766) grant. Dr. Misako Urabe and Yuko Goto (University of Shiga Prefecture) provided assistance in the field in Hikone. We also thank M. Kawato, E. Fujiwara, and F. Pradillon for their help in the JAMSTEC molecular laboratory. Dr. Csaba Csuzdi from Hungarian National University, Budapest kindly commented on an earlier draft, and Yuko Hiramoto assisted with translation of some Japanese papers. Dr. Jotaro Urabe of the Department of Biology, Tohoku University and Dr. Jun Nemoto at the Tohoku University Natural History Museum, and Dr. Masaaki Tomokuni, head of Zoology at the National Museum of Nature and Science, Tokyo and Dr. Toshiaki Kuramochi, the Annelida curator there, are all thanked for confirmation of the absence of Dr. Shinkishi Hatai's Drawida hattamimizu materials at their respective institutions. 


\section{References}

[For brevity, not all taxonomic citations are included. Anon. = Anonymous author(s)].

Anon. (1997) Red Data Book of Russian Federation. http://enrin.grida.no/biodiv/biodiv/ national/russia/state/00440.htm

Anon. (2007) Red Data Book of Japan. http://www.biodic.go.jp/english/J-IBIS.html

Anon. (2008) Biotechnology and Biological Sciences Research Council (2008, October 19). Opening A Can Of Worms: Serendipitous Discovery Reveals Earthworms More Diverse Than First Thought. ScienceDaily. http://www.sciencedaily.com/releases/2008/10/081010081652.htm [accessed August 4, 2009]

Anon. (2009) Red Data book for Ishikawa-ken. http://www.pref.ishikawa.jp/sizen/reddata/ RDB_2009/4_ato/kennsaku2/9-1hattajyuzuimimizu.pdf

Anon. (2010) Wikipedia article on botanical 'microspecies'. http://en.wikipedia.org/wiki/ Apomixis [accessed 13.I.2010]

Bely AE, Wray GA (2004) Molecular phylogeny of naidid worms (Annelida : Clitellata) based on cytochrome oxidase I. Molecular Phylogenetics and Evolution 30: 50-63.

BenhamWB (1890) An Attempt to Classify Earthworms. Quarterly Journal of Microscopy Science XXXI 1890 175-200. http://jcs.biologists.org/cgi/reprint/s2-31/122/201.pdf

Blakemore RJ (1994) Earthworms of south-east Queensland and their agronomic potential in brigalow soils. PhD thesis, Brisbane, Queensland: University of Queensland.

Blakemore RJ (1995) A curatorial inventory of earthworms in the ANIC earthworm collection. CSIRO, Division of Entomology, Canberra. http://bio-eco.eis.ynu.ac.jp/eng/database/ earthworm/Australasian\%20Earthworms\%5CRegister.xls

Blakemore RJ (1999) The diversity of exotic earthworms in Australia - a status report. In: Ponder W, Lunney D (Eds) Proceedings of “The Other 99\%”. Transactions of the Royal Zoological Society of NSW, 1999: 182-187. http://bio-eco.eis.ynu.ac.jp/eng/ database/earthworm/Australasian\%20Earthworms\%5CAustralian\%20Exotics.pdf or http://biocollections.org/pub/worms/docs/Blakemore-eworms-Diversity-of-exotics. html

Blakemore RJ (2000a) Tasmanian Earthworms. CD-ROM Monograph with Review of World Families. 'VermEcology', Canberra, 800pp.

Blakemore RJ (2000b) Ecology of earthworms under the "Haughley Experiment" of organic and conventional management regimes. Biological Agriculture \& Horticulture 18(2): 141159. http://bio-eco.eis.ynu.ac.jp/eng/database/earthworm/Haughley\%5CHaughley.pdf

Blakemore RJ (2002) Cosmopolitan Earthworms - an Eco-Taxonomic Guide to the Peregrine Species of the World. VermEcology, Kippax, Australia, 426 pp.

Blakemore RJ (2003) Japanese Earthworms (Annelida: Oligochaeta): a Review and Checklist of Species. Organisms, Diversity and Evolution 3(3): 241-244.

Blakemore RJ (2005) Whither Octochaetidae? - A review of its family status (Annelida: Oligochaeta). In: Pop AA, Pop VV (Eds) Advances in Earthworm Taxonomy II. Proceedings IOTM2, Cluj University Press. Romania: 63-84. 
Blakemore RJ (2007a) Chapters in: A Series of Searchable Texts on Earthworm Biodiversity, Ecology and Systematics from Various Regions of the World. In: Ito MT, Kaneko N (eds) CD-ROM publication by Soil Ecology Research Group, Graduate School of Environment \& Information Sciences, Yokohama National University, 79-7 Tokiwadai, Yokohama 240-8501, Japan. http://bio-eco.eis.ynu.ac.jp/eng/database/earthworm/ [accessed March, 2007].

Blakemore RJ (2007b) Review of Criodrilidae (Annelida : Oligochaeta) including Biwadrilus from Japan. Opuscula Zoologica 37: 11-22. http://opuscula.elte.hu/PDF/Tomus37/2_ Review\%20of\%20Criodrilidae.pdf

Blakemore RJ (2007c) Helodrilus hachiojii sp. nov. (Oligochaeta: Lumbricidae) from Japan. Edaphologia 82: 17-25. http://www.soc.nii.ac.jp/jssz/htmls/Edaphologia/Edaphol50E. html

Blakemore RJ (2008a) Cosmopolitan earthworms - an Eco-Taxonomic Guide to the Species ( $3^{\text {rd }}$ Edition). VermEcology, Yokohama, Japan, 757pp.

Blakemore RJ (2008b) Phylogeny of Megascolecidae revisited with recourse to non-molecular means. In: Pavlíček T, Cardet P (Eds) Advances in earthworm taxonomy III (Annelida: Oligochaeta). The Environment of Service of the Ministry of Agriculture, Natural Resources and Environment of Cyprus, Nicosia: 11-22.

Blakemore RJ (2008c) Review of Oriental pheretimoids (Pheretima auct. Megascolecidae) with description of a new genus. In: Pavlíček T, Cardet P (Eds) Advances in earthworm taxonomy III (Annelida: Oligochaeta). The Environment of Service of the Ministry of Agriculture, Natural Resources and Environment of Cyprus, Nicosia: 23-36.

Blakemore RJ (2009) Cosmopolitan earthworms - a global and historical perspective. Chapter 14. In: Shain DH (Ed) Annelids as Model Systems in the Biological Sciences. John Wiley \& Sons, NewYork, 257-283.

Blakemore RJ (in press) Saga of Herr Hilgendorf's worms. In: Pavlicek T, Csuzdi Cs (Eds) IOTM Book of Abstracts. Dicle University, Diyarbakır, Turkey.

BOLD (2010) Barcode of Life Systems online informatics workbench facility. http://www. boldsystems.org/views/login.php [accessed 23.II.2010]

Briones MJI, Morán P, Posada D (2009) Are the sexual, somatic and genetic characters enough to solve nomenclatural problems in lumbricid taxonomy? Soil Biology \& Biochemistry 41(11): 2257-2271.

CBOL (2010) 'Protocols'. Consortium for the Barcode of Life. Barcode of Life Secretariat C/- National Museum of Natural History, Washington, DC. http://www.barcoding.si.edu/ protocols.html [accessed 23.II.2010]

Cech G, Csuzdi Cs, Marialigeti K (2005) Remarks on the molecular phylogeny of the genus Dendrobaena (sensu Pop 1941) based on the investigation of 18 S rDNA sequences. In: Pop AA, Pop VV (Eds) Advances in Earthworm Taxonomy II. Proceedings IOTM2, Cluj University Press, Romania: 85-98.

Chang C-H, Lin S-M, Chen J-H (2008) Molecular systematics and phylogeography of the gigantic earthworms of the Metaphire formosae species group (Clitellata, Megascolecidae), Molecular Phylogenetics and Evolution 49: 958-968. 
Chang C-H, Rougerie R, Chen J-H (2009) Identifying earthworms through DNA barcodes: Pitfalls and promise. Pedobiologia 52: 171-180. doi: 10.1016/j.pedobi.2008.08.002.

Darwin CR (1881) The Formation of Vegetable Mould through the Action of Worms with Observations on their Habits. Murray, London, 326pp.

Dominguez J, Velando A, Ferreiro A (2005) Are Eisenia fetida (Savigny, 1926) and Eisenia andrei Bouché (1972) (Oligochaeta, Lumbricidae) different biological species? Pedobiologia 49: 81-87.

Easton EG (1981) Japanese earthworms: a synopsis of the Megadrile species (Oligochaeta). Bulletin of the British Museum (Natural History) Zoology 40(2): 33-65.

Easton EG (1984) Earthworms (Oligochaeta) from islands of the south-western Pacific, and a note on two species from Papua New Guinea. New Zealand Journal of Zoology 11: 111-128.

Folmer O, Black M, Hoeh W, Lutz R, Vrijenhoek R (1994) DNA primers for amplification of mitochondrial cytochrome c oxidase subunit I from diverse metazoan invertebrates. Molecular Marine Biology and Biotechnology 3: 294-297.

Gates GE (1959) On a taxonomic puzzle and the classification of the earthworms. Bulletin of the Museum of Comparative Zoology, Harvard 121(6): 229-261.

Gates GE (1962) On some Burmese earthworms of the moniligastrid genus Drawida. Bulletin of the Museum of Comparative Zoology, Harvard 127: 297-373.

Gates GE (1972) Burmese Earthworms, an introduction to the systematics and biology of Megadrile oligochaetes with special reference to South-East Asia. Transactions of the American Philosophical Society 62(7): 1-326.

Goto S, Hatai S (1898) New or imperfectly known species of earthworms. No. 1. Annotationes Zoologicae Japonensis 2: 65-78.

Goto S, Hatai S (1899) New or imperfectly known species of earthworms. No. 2. Annotationes Zoologicae Japonensis 3(1): 13-24.

Gregory TR, Hebert PDN (2002) Genome size estimates for some oligochaete annelids. Canadian Journal of Zoology 80: 1485-1489.

Hatai S (1930) On Drawida hattamimizu, sp. nov. Science Reports of the Tohoku Imperial University. 4th Series. Biology 5(3): 485-508.

Hatai S (1931) Mimizu (Earthworms). Kaizou Sha, Tokyo, 218 pp. [In Japanese].

Huang J, Xu Q, Sun ZJ, Tang GL, Su ZY (2007) Identifying earthworms through DNA barcodes. Pedobiologia 51: 301-309. doi: 10.1016/j.pedobi.2007.05.003

ICZN (1999) International Code of Zoological Nomenclature ( $4^{\text {th }}$ edition). International Trust for Zoological Nomenclature, London, 306 pp.

Jaenike J (1982) 'Eisenia foetida' is two biological species. Megadrilogica 4(1-2): 6-8.

JTYPES (2009) Database of Japanese type specimens. Union of Japanese Societies for Systematic Biology online facility: http://foj.c.u-tokyo.ac.jp/jtypes/index-j.html [accessed 11.XI.2009].

Kamihira, Y (2005) Fauna and Distribution of Moniligastrida (Terrestrial Oligochaeta) in and around Japan : Zoogeographical consideration of the primitive earthworm. Bulletin of Hakodate Junior College 31: 1-9. [in Japanese] 
King RA, Tibble AL, Symondson WOC (2008) Opening a can of worms: unprecedented sympatric speciation within British lumbricid earthworms. Molecular Ecology 17: 4684-4698. doi:10.1111/j.1365-294X.2008.03931.x.

Kobayashi S (1941) Earthworms. Japanese Zoological Magazine 53: 258-266. [In Japanese].

Krell F-T (2004) Parataxonomy vs. taxonomy in biodiversity studies - pitfalls and applicatbility of 'morphospecies' sorting. Biodiveristy and Conservation 13: 795-812.

Lowe CN, Butt KR (2007) Life cycle traits of the dimorphic earthworm species Allolobophora chlorotica (Savigny, 1826) under controlled laboratory conditions. Biology \& Fertility of Soils 43: 495-499.

Lowe CN, Butt KR (2008) Allolobophora chlorotica (Savigny, 1826): Evidence for classificaton as two separate species. Pedobiologia 52: 81-84.

Michaelsen W (1900) Das Tierreich Vol. 10: Vermes, Oligochaeta. Friedländer \& Sohn, Berlin, XXIX+575pp.

Nishino, M (2006) Drawida hattamimizu. Red Data Book of Shiga Prefecture, 2005, Wildlife Survey Group in Shiga Prefecture, Sunrise Press, Shiga, 563pp.

Ogawa F (1944) Mimizu no Kansatsu (Examining Earthworms), Sogensha, Tokyo [in Japanese].

Ohfuchi S (1938a) Zoological observations of the earthworms of the genus Pheretima from the ricefield in Ishikai, Hokkaido. Botany Zoology, Tokyo 6(12): 1991-1998 (issue pagination 21-28). [In Japanese].

Ohfuchi S (1938b) On the Cocoon of Drawida hattamimizu Hatai. Japanese Zoological Magazine, Tokyo, 50(8): 395-397. [In Japanese].

Øien N, Stenersen J (1984) Esterases of earthworms III. Electrophoresis reveals that Eisenia fetida (Savigny) is two species. Comparative Biochemistry and Physiology - Part C 78: 277-282.

Pleijel F, Jondelius U, Norlinder E, Nygren A, Oxelman B, Schander C, Sundberg P, Thollesson M (2008) Phylogenies without roots? A plea for the use of vouchers in molecular phylogenetic studies. Molecular Phylogenetics and Evolution 48: 369-371.

Pérez-Losada M, Eiroa J, Mato S, Domínguez J (2005) Phylogenetic species delimitation of the earthworms Eisenia fetida (Savigny, 1826) and Eisenia andrei Bouché, 1972 (Oligochaeta, Lumbricidae) based on mitochondrial and nuclear DNA genes. Pedobiologia 49: 317-324.

Pérez-Losada M, Ricoy M, Marshall J, Domínguez J (2009) Phylogenetic assessment of the earthworm Aporrectodea caliginosa species complex (Oligochaeta: Lumbricidae) based on mitochondrial and nuclear DNA sequences. Molecular Phylogenetics and Evolution 52(2): 293-302.

Reynolds JW, Cook DG (1976) Nomenclatura Oligochaetologica: a catalogue of names, descriptions and type specimens of the Oligochaeta. University of New Brunswick, Fredericton, 217 pp.

Rougerie R, Decaëns T, Deharveng L, Porco D, James S, Chang C-H, Richard B, Potapov M, Suhardjono Y, Hebert PDN (2009) DNA barcodes for soil animal taxonomy. Pesquisa Agropecuária Brasileira 44(8): 789-801. 
Siddall ME, Apakupakul K, Burreson EM, Coates KA, Erséus C, Gelder SR, Källersjö M,

Trapido-Rosenthal H (2001) Validating Livanow's hypothesis: molecular data agree that Leeches, Branchiobdellidans and Acanthobdella peledina form a Monophyletic Group of

Oligochaetes. Molecular Phylogenetics and Evolution 21:346-351.

Siddall ME, Fontanella FM, Watson SC, Kvist S, Erséus C (2009) Barcoding bamboozled by bacteria: convergence to Metazoan Mitochondrial primer targets by marine microbes. Systematics Biology 58: 445-451.

Sims RW (1980) A Classification and the distribution of earthworms, suborder Lumbricina (Haplotaxida: Oligochaeta). Bulletin of the British Museum (Natural History) Zoology 39: 103-124.

Sims RW, Gerard BM (1985) Earthworms. Keys and notes to the identification and study of the Species. Synopsis of the British Fauna (New series). No. 31. E.J. Brill, Leiden, 171pp.

Sims RW, Gerard BM (1999) Earthworms: Notes for the identification of British species. $4^{\text {th }}$ Edition. Published for The Linnean Society of London and The Estuarine and Coastal Sciences Association by Field Studies Council, Montford Bridge, Shrewsbury, UK, 169pp.

Stephenson J (1923) The fauna of British India, including Ceylon and Burma. Oligochaeta. Taylor \& Francis, London, 518 pp.

Stephenson J (1930) The Oligochaeta. Oxford University, Clarendon Press, 978 pp.

Stürzenbaum SR, Andre J, Kille P, Morgan AJ (2009) Earthworm genomes, genes and proteins: the (re)discovery of Darwin's worms. Proceedings of the Royal Society, B 276(1658): 789-797.

Uchida T (1988) Drawida japonica cf. D. hattamimizu. In: Okada Y, Uchida S, Uchida T (Eds) New Illustrated Encyclopedia of the Fauna of Japan (Shinpen Nihon Doubutsu Zukan), Part I, Hokuryukan, Tokyo, 803 pp. [In Japanese].

Uenishi M (in press) Note on "Hattamimizu" in the paddy fields from near Mikata Lake, in Mikata Five Lakes, Wakasa-cho, Fukui Prefecture. Fukui Rikusui Seibutsu Kaiho 16. [in Japanese].

van Praagh BD (1992) The biology and conservation of the giant Gippsland earthworm Megascolides australis McCoy, 1878. Soil Biology and Biochemistry 24: 1363-1367.

Watanabe H (2005) On hatta mimizu (Drawida hattamimizu), a unique semi-aquatic earthworm, distributed around the Lake Biwa and it's conservation. KONC, Bulletin of Kansai Organization for Nature Conservation 27 (2): 5-19. [In Japanese].

Yuki H (1940a) Hakubutsu danpen (sono 1). Omi Hakubutsu Dokokaishi 8: 16-25. [in Japanese].

Yuki H (1940b) Hakubutsu danpen (sono 2). Omi Hakubutsu Dokokaishi 9: 11-15. [in Japanese]. 


\section{Appendix}

The primer sets used, LCO1490 and HCO2198, amplify a 658 bp fragment of the COI gene in a wide range of invertebrate taxa (Folmer et al 1994):

LCO1490: 5'-GGTCAACAAATCATAAAGATATTGG-3'

HCO2198: 5'-TAAACTTCAGGGTGACCAAAAAATCA-3'

For Oli 5 only ( $D$. hattamimizu Neotype) modified Folmer primer was used (Bely \& Wray, 2004) for the reverse modified primer (the forward was the standard LCO Folmer primer), viz.:

5'-TATACTTCTGGGTGTCCGAAGAATCA-3’:

Sequence data differences between $D$. hattamimizu specimens below are indicated by bolding and, whereas the 616 common sequential nucleotides agree $100 \%$ for the Neotype and topotype, the Hikone specimen (with 613 bases) differs in only 7 (bold) $=-1.14 \%$ real difference in sequences identity (standard errors not applied); this small variation supports its acceptance as the same taxon.

Hikone Drawida cf. japonica sequence is included for general comparison; it differs considerably from Genbank EF077597 ["Drawida japonica COI-5P”]: of the 607 consecutive bases, approximately 104 differ $(=17.13 \%)$, thus conspecificity of these non-type Chinese specimens is not wholly supported.

Seq 1 GenBank Accession No. (submitted 20.VIII.2009) GQ500899.

Oli5 Drawida hattamimizu... Spec No. 1 (LBM1380000078) Neotype 21.vi.2002 ex Hatta $85 \%$ EtOH.

AGGTGTATGAGCTGGAATAATCGGGGCTGGTATAAGACTTCTTATTCGAATTGAACTAAGACAGCCTGGAACATTTTTAGGGAGTGATCAATTATATAATACTATTGTTACAGCACATGCGTTTATTATAATTTTCTTCTTAGTTATACCAGTATTTATTGGGGGGTTTGGTAACTGGCTTCTTCCTTTAATACTGGGGGCACCAGATATAGCATTTCCACGACTTAATAATTTAAGATTTTGATTACTCCCACCATCTTTAATTTTATTAGTTTCCTCAGCTGCTGTTGAAAAGGGGGCAGGAACAGGTTGAACTGTATACCCCCCATTAGCCAGAAATATTGCACATGCTGGTCCGTCAGTAGACTTAGCTATTTTTTCTCTTCATTTGGCAGGTGCCTCATCTATCTTAGGAGCTATTAATTTTATTACAACAGTGATTAATATACGATGAGCTGGACTCCAGTTAGAGCGTATTCCACTTTTTGTGTGGGGAGTATTTATCACTGTAATTCTTCTTCTTTTATCTCTCCCAGTATTAGCCGGAGCCATTACAATACTACTAACAGATCGTAATTTAAATACATCATTTTTTGACCCTGCTGGTGGGGGTGAT

BLAST Hormogaster elisae haplotype LOZ4 cytochrome oxidase subunit I (COI) gene, partial cds; mitochondrial Length $=648$ 
Seq 2 GenBank Accession No. (submitted 20.VIII.2009) GQ500900.

Oli3 Drawia hattamimizu... Ex Hatta (topotype) 10.ix.2008 Spec No. 2 (LBM1380000082) in 85\% EtOH.

TTTtATTTTAGGTGTATGAGCTGGAATAATCGGGGCTGGTATAAGACTTCTTATTCGAATTGAACTAAGACAGCCTGGAACATTTTTAGGGAGTGATCAATTATATAATACTATTGTTACAGCACATGCGTTTATTATAATTTTCTTCTTAGTTATACCAGTATTTATTGGGGGGTTTGGTAACTGGCTTCTTCCTTTAATACTGGGGGCACCAGATATAGCATTTCCACGACTTAATAATTTAAGATTTTGATTACTCCCACCATCTTTAATTTTATTAGTTTCCTCAGCTGCTGTTGAAAAGGGGGCAGGAACAGGTTGAACTGTATACCCCCCATTAGCCAGAAATATTGCACATGCTGGTCCGTCAGTAGACTTAGCTATTTTTTCTCTTCATTTGGCAGGTGCCTCATCTATCTTAGGAGCTATTAATTTTATTACAACAGTGATTAATATACGATGAGCTGGACTCCAGTTAGAGCGTATTCCACTTTTTGTGTGGGGAGTATTTATCACTGTAATTCTTCTTCTTTTATCTCTCCCAGTATTAGCCGGAGCCATTACAATACTACTAACAGATCGTAATTTAAATACATCATTTTTTGACCCTGCTGGTGGGGGTGATC-

\section{CTATTT}

BLAST Hormogaster elisae haplotype LOZ4 cytochrome oxidase subunit I (COI) gene, partial cds; mitochondrial Length $=648$

Seq 3 GenBank Accession No. (submitted 20.VIII.2009) GQ500901.

Oli2 - D. hattamimizu... Hikone Spec. 18.vi.2009 No. 3 (LBM1380000084) 99.5\% EtOH.

xxxTGTATGAGCTGGAATAATCGGGGCTGGTATAAGACTTCTTATTCGAATTGAACTAAGACAGCCTGGAACATTTTTAGGGAGTGATCAGTTATATAATACTATTGTTACAGCACATGCATTTATTATAATTTTCTTCTTAGTTATACCAGTATTTATTGGGGGGTTTGGTAACTGACTTCTTCCTTTAATACTGGGGGCACCAGATATAGCATTTCCACGACTTAATAATTTAAGATTTTGATTACTTCCACCATCTTTAATTTTATTAGTTTCCTCAGCTGCTGTTGAAAAGGGGGCAGGAACAGGTTGAACTGTATACCCCCCATTAGCCAGAAATATTGCACATGCTGGTCCGTCGGTAGACCTAGCTATTTTTTCTCTTCATTTGGCAGGTGCCTCATCTATCTTAGGAGCTATTAATTTTATTACAACAGTGATTAATATACGATGAGCTGGACTCCAGTTAGAGCGTATTCCACTTTTTGTGTGGGGAGTATTTATCACTGTAATTCTTCTTCTTTTATCTCTCCCAGTATTAGCCGGAGCCATTACAATACTACTAACAGATCGTAATTTAAATACATCATTTTTTGACCCTGCTGGTGGGGGCGATCCTATTT

BLAST Hormogaster elisae haplotype LOZ4 cytochrome oxidase subunit I (COI) gene, partial cds; mitochondrial Length=648 82\% identity. 
Seq 4 GenBank Accession No. (submitted 20.VIII.2009) GQ500902.

Oli4 Drawida cf. japonica Hikone 85\%EtOH Spec No. 4 (LBM1380000085). GAGCTGGAaTAATTGGTGCAGGCATGAGGTTATTAATTCGAATTGAGTTAAGGCAACCAGGTTCATTTTTAGGTAGAGATCAGCTTTACAACACTATTGTTACTGCACATGCTTTTATTATAATTTTTTTCTTGGTAATACCGGTATTTATTGGCGGTTTTGGTAATTGATTGCTCCCATTAATACTTGGTGCCCCAGATATGGCTTTTCCTCGACTAAATAATTTAAGATTTTGACTTTTGCCTCCTGCCCTAATTCTTTTAGTGTCTTCGGCAGCAGTGGAAAAAGGTGCTGGTACTGGGTGAACAGTTTACCCACCCTTAGCTAGTAATTTAGCACATGCGGGCCCATCTGTTGACTTGGCGATTTTTTCTTTACATTTAGCAGGTGCTTCTTCTATTTTAGGGGCAATTAATTTTATTACGACTATTATTAACATGCGCTGAGCAGGTATACACTTTGAGCGAATTCCATTATTTGTGTGGGGAGTTTTAATTACTGTGGTACTATTGCTTCTATCTTTACCTGTGTTGGCTGGCGCAATTACTATGCTTTTAACCGATCGAAATTTAAATACTTCATTTTTTGATCCGGCTGGTGGAGGAGATCCTATTT

BLAST Drawida japonica japonica voucher 06-273 cytochrome c oxidase subunit I (COI) gene, partial cds; mitochondrial Length $=640$ 83\%

Cf. Genbank Accession No. EF077597 [“Drawida japonica COI-5P”] from Huang et al. vouchers.

xxxxxxxxxATAATTGGAGCCGGCATAAGACTATTAATTCGAATTGAATTAAGTCAACCTGGTACTTTTTTAGGTAGAGATCAACTTTATAACACTATTGTTACTGCTCATGCATTTATCATAATTTTCTTTTTAGTAATACCAGTTTTTATTGGTGGATTTGGTAATTGGTTATTACCTCTTATACTAGGTGCACCAGATATAGCATTTCCTCGATTAAACAATTTAAGATTTTGGTTATTACCCTCTGCATTAATTCTTTTAGTATCTTCCGCAGCCGTGGAAAAAGGTGCGGGTACTGGATGAACAGTTTACCCGCCTCTCGCTAGAAATCTGGCTCACGCCGGACCGTCTGTAGACCTAGCAATTTTTTCTTTACATTTAGCAGGTGCTTCTTCTATTTTAGGTGCAATTAATTTTATTACTACTGTTGTAAACATGCGATGAGCTGGAATACATTTTGATCGAATTCCTTTGTTTGTATGGGGGGTATTAATTACTGTAGTTTTGCTATTACTTTCCTTACCTGTACTAGCTGGTGCAATTACTATACTTTTAACCGACCGAAATTTAAACACGTCTTTTTTTGATCCCGCAGGAGGCGGAGACCCTATTTTATATCAACATTTATTTTGATTTTTTGGTCACC 